\title{
Comparative Analysis of $p H$ Level Between Pasteurized and UTH Milk Using Dedicated Developed Application
}

\begin{abstract}
COSMINA MIHAELA ROSCA ${ }^{1 *}$, MARIAN POPESCU1', CRISTIAN PATRASCIOIU1, ADRIAN STANCU ${ }^{2}$
'Petroleum-Gas University of Ploiesti, Automatic Control, Computers and Electronics Department, 39 Bucuresti Blvd., 100680, Ploiesti, Romania

2Petroleum-Gas University of Ploiesti, Faculty of Economic Sciences, 39 Bucuresti Blvd., 100680, Ploiesti, Romania

The paper presents a study regarding the $\mathrm{pH}$ evolution of pasteurized and UHT milk in different situations. $A$ comparative analysis is presented between both products using the same conditions. Firstly, the milk was analyzed at the ambient temperature of a room, set to $23^{\circ} \mathrm{C}$. The $\mathrm{pH}$ values are acquired every half an hour for 2 days, using a $\mathrm{pH}$ meter. In this way, the evolution in time from low-acid to medium-acid of the milk is compared for both products. A dedicated computer application was developed to perform the data processing and storage in a database. Next, a comparative graphical representation is used to analyze the results. Secondly, a comparative analysis is performed for pasteurized and UHT milk by modifying the temperature starting with to the boiling point. The changes that occurs during the temperature evolution are discussed based on $\mathrm{pH}$ values evolution.
\end{abstract}

Keywords: pH, UHT, pasteurized, milk, measurement system, database

In the last century, scientific evolution has experienced an expansion in various fields of activity. Computer science has allowed the evolution of different domains, one of the most important of which is chemistry.

By definition, $\mathrm{pH}$ represents a convenient measure of the acidity or alkalinity of a solution at a specified temperature [1]. There are lots of researches regarding pH in different areas, such as medicine [2], cosmetics industry $[3,4]$, sanitation (wastewater treatment) [5] or food industry [6].

Food industry is focused in the last decade on converting the products perishability into a long-term product. As mentioned in paper [7] the threated product should maintain the sensors (flavor) and the same nutritional characteristics as the original (unprocessed) product. Paper [8] presents a detailed study regarding milk. According to this paper, pasteurization is a preservation method using the heating with the main purpose to destroy disease causing and spoilage organism to prevent fermentation. The pasteurization process refers to four categories of products differentiated by the combination of time and temperature: HTST (High Temperature Short Time $-71.6^{\circ} \mathrm{C}$ -15 seconds), HHST (High Heat Short Time -more than $71.6^{\circ} \mathrm{C}$ ), UP (Ultra Pasteurized $-137.7^{\circ} \mathrm{C}-2$ seconds) and UHT (Ultra High Temperature -milk is heated until sterile) [8].

The first three categories will be referred in the current paper as pasteurized milk and the fourth category is represented by the UHT. According to paper [9], milk quality indicators are fat and protein. After a specified time, the milk increases its viscosity [10], so in this paper a new correlation between time - temperature - viscosity will be proposed using the $\mathrm{pH}$ level. Paper [11] mention that the cow milk $p H$ is 6.5 - 6.7 and as it becomes sourer when the $\mathrm{pH}$ gets lower values. As the $\mathrm{pH}$ of milk depends on species, in this paper the cow milk will be considered.

The studies presented in paper [12] shows that cow fresh milk has a pH between $6.5-6.7$, while higher values than 6.8 denotes condensed milk and lower values than 6.5 represents the presence of bacterial deterioration. Paper [13] illustrates that pH value is different for buffalo, cow, goat and sheep. Besides this, the decreases of the $\mathrm{pH}$ is normal because of the bacterial increasing presence [13].Comprehensive analyses for chemical composition of milk versus $\mathrm{pH}$ has been presented in papers [14-16].

The $\mathrm{pH}$ is an important parameter for both products and solution. A detailed analysis of $\mathrm{pH}$ solutions is described in paper [17]. Further, a detailed analysis regarding the $\mathrm{pH}$ of products such as milk will be carried on.

As mentioned in paper [18], lactic acid, with the formula $\mathrm{CH} 3-\mathrm{CHOH}-\mathrm{COOH}$, has an asymmetric carbon atom in the molecule, and as consequence, the lactic acid might have a dextrogir isomer, one levogir and one racemic form. Racemic lactic acid is also called lactic acid fermentation and is formed in sugars such as glucose, sucrose and lactose under the influence of enzymes produced bylactic acid bacteria. This type of acid appears in sour milk, acacia and pickles. Lactic fermentation of sugars is described by the following formula:

$$
\mathrm{C}_{6} \mathrm{H}_{12} \mathrm{O}_{6} \rightarrow 2 \mathrm{C}_{3} \mathrm{H}_{6} \mathrm{O}_{3} \text {. }
$$

Lactic acid, which is hard to purify because of the water, is obtained by distillation in a vacuum in the form of melting crystals. Lactic acid is mixed in any percentage with water, alcohol and ether, and can be cleaved into the enantiomers by crystallization of the strychnine, quinine, or morphine salts. It is unusual that racemic lactic acid and one of the optically active forms are obtained by fermentation [18].

Lactose crystallizes at room temperature in the anomer $\alpha$, and over $93^{\circ} \mathrm{Cin}$ the anomer $\beta$.It is contained in concentrated milk of $4-6 \%$ and is isolated by concentrating whey. Lactose is converted to lactic acid by lactic acid bacteria [18].

One of the most important factors involved in pH milk evolution is the temperature [19]. The heating process will destroy the microbial population and as consequence the $\mathrm{pH}$ value will increase $[20,21]$. Based on this issue, we expect that increasing the temperature, the $\mathrm{pH}$ level will increase.

In this paper, multiple experiments will be presented with the main purpose to analyze the $\mathrm{pH}$ evolution for pasteurized versus UHT cow milk at the same temperature. The first stage measurements will analyze the $\mathrm{pH}$ evolution for an extended interval of time. The second stage

* email: cosmina.rosca@upg-ploiesti.ro 
measurements will show the $\mathrm{pH}$ evolution by varying the temperature for a short interval of time.

A second issue that will concern the experimental part is represented by a constant $p H$ level for the UHT against pasteurized cow milk.

\section{Experimental part}

\section{$\mathrm{pH}$ measuring system}

In our research, the experimental setup (presented in figures $1 \mathrm{a}$ and $1 \mathrm{~b}$ ) involves:

-commercial cow milk (pasteurized and UHT cow milk available in market);

-two pH meters connected to the PC via USB (figures laand $1 \mathrm{~b}$ );

-Arduino Uno board used to convert electrical value to $\mathrm{pH}$ level from milk probes to PC;

-Matlab ${ }^{\circledR}$ application used to acquire the date from $\mathrm{pH}$ meter and store the values into a database for further postprocessing.

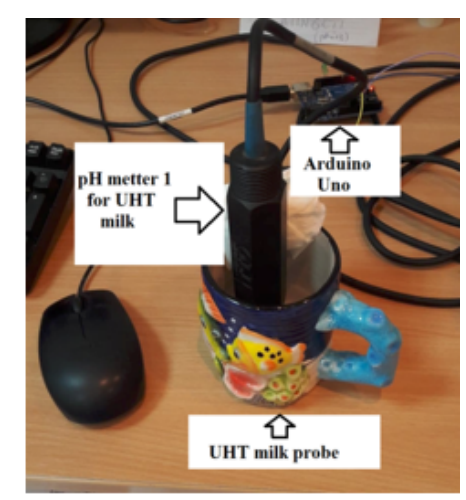

Fig. 1a. pH meter used to test UHT milk probe

pH meter process calibration

Before measurement process, a calibration process is needed. The calibration procedure is made as follows:

-Step 1:The $\mathrm{pH}$ meter probes are rinsed in deionized water and next, a soft tissue is used to remove the solution on electrodes;

-Step 2:The probes (electrodes) are inserted into a 7.00 $\mathrm{pH}$ solution;

-Step 3: Step 1 is repeated;

-Step 4: The probes (electrodes) are inserted into a 7.00 $\mathrm{pH}$ solution;

-Finally, the pH meter display should indicate Calibration successful.

\section{Structure of the experiments}

The experiments are made by modifying different variables involved in the milk process. For a comparative analysis between UHT and pasteurized milk, two transducers were calibrated using the same solutions and identical environmental conditions.

Test $T_{1}$ :

-isothermal conditions: $23^{\circ} \mathrm{C}$ (ambient temperature);

-transient time: 38 hours (2280 minutes);

-objective: $\mathrm{pH}$ evolution in time.

The milk samples were allowed to reach the room temperature, set up to $23^{\circ} \mathrm{C}$. The electrodes of the $\mathrm{pH}$ meters are introduced into probes of milk. The monitor application is started and a sample for UHT milk and another one for pasteurized milk is acquired every 15 minutes. The process continues for 220 samples, which means 55 hours. The process was stopped because the $\mathrm{pH}$ reached a medium acid value.
Test $T_{2}$ :

-initial temperature: $12^{\circ} \mathrm{C}$;

-final temperature: $23^{\circ} \mathrm{C}$;

-objective: $\mathrm{pH}$ evolution for a temperature variation.

Test $\mathrm{T}_{2}$ compares the $\mathrm{pH}$ values for a temperature variation between $2.7-23.1^{\circ} \mathrm{C}$, and is related to the data acquisition acquired after the products unpacking. The measurements were provided every 20 minutes for 520 minutes.

Test $T_{3}$ :

-slow temperature variation: $22-23^{\circ} \mathrm{C}$;

-same probes of milk after 12 hours after unboxing;

-objective: $\mathrm{pH}$ evolution in the area of the soaking milk process.

For the third test, the $\mathrm{pH}$ measurements continue after 12 hours, with the same probes of milk.

\section{Results and discussions}

Test $T_{1}$

Figure 2 presents the $\mathrm{pH}$ evolution for UHT and pasteurized milk. In this figure, it can be seen that at the beginning, the $\mathrm{pH}$ for UHT milk is 6.6 and has a lower value than the pasteurized milk whose value is 6.8. These values show that the 0.2 difference is introduced by the processing treatments as the UHT has a higher sterilization temperature than the pasteurization temperature. The values illustrate that sterilization process reduce the $\mathrm{pH}$ of milk.

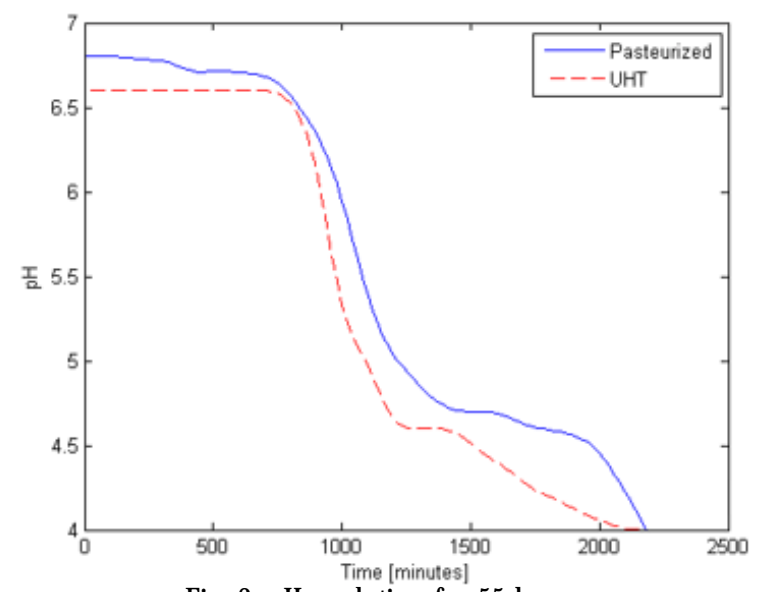

Fig. 2. $\mathrm{pH}$ evolution for 55 hours

Analyzing the milk evolution for 55 hours, as it can be seen in figure 2 , the UHT at $23^{\circ} \mathrm{C}$ has a constant $\mathrm{pH}$ value for the first 24 hours, while the one of the pasteurized milk slowly decreases. Next days, the $\mathrm{pH}$ value decreases from 6.5 to 4 which means that the acidity has been increased. This $\mathrm{pH}$ evolution is due to the lactic acid obtain by the lactose of the sour milk. By the comparative analysis between the two milk products, the UHT has a stable pH value for the first day, but the sour level is increased faster than the pasteurized milk.

The result of this experiment shows that the $\mathrm{pH}$ evolution in time has a lower variation on the first day in both cases ( 6.6 for UHT milk, and $6.8-6.6$ for pasteurized milk), and the $\mathrm{pH}$ level decreases in the next two days until the milk becomes sour with a acidity level of $\mathrm{pH}=4$.

In order to obtain a mathematical model for the $\mathrm{pH}$ variation from this experiment, another application in Matlab ${ }^{\circledR}$ environment was developed. Based on the experimental data, and using functions from System Identification Toolbox, this application has as result the third-order model (as transfer function) from relation (1):

$$
G(s)=\frac{K \omega_{n}^{2}}{\left(s^{2}+2 \zeta \omega_{n} s+\omega_{n}^{2}\right)\left(T_{3} s+1\right)},
$$


where: $K$ is the system gain; $\omega_{n}$ - natural frequency of the system; $\zeta$ - damping factor; $T_{3}$ - time constant.

The model output obtained at step input and the experimental data are compared in figure 3.

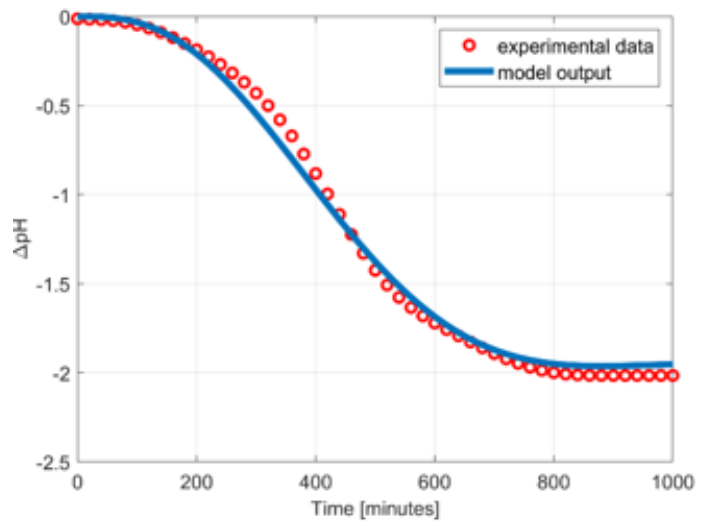

Fig. 3. Experimental data vs. identified model for the $\mathrm{pH}$ variation $(\Delta \mathrm{pH})$

The values for the parameters of the transfer function from relation (1) are: $\mathrm{K}=-0.11 ; \omega_{\mathrm{n}}=0.071[\mathrm{l} / \mathrm{min}] ; \zeta=0.3$; $\mathrm{T}_{3}=435[\mathrm{~min}]$.

${ }^{3}$ In order to determine the model suitability, the mean squared error (MSE) between experimental data and model output is calculated with relation (2):

$$
\text { MSE }=\frac{1}{n} \sum_{i=1}^{n}\left(y_{i}-\hat{y}_{i}\right)^{2},
$$

where: $n$ is the number of samples; $y_{i}$ - measured values; $\hat{y}_{i}$ - estimated values.

For the studied case, the mean squared error is less than $1 \%$, thus indicating a very good accuracy of the identified model, which means that itcan be used in further research.

The second stage experiment targets the evolution of the milk pH with temperature for the same products.

\section{Test $T_{2}$}

This time, the milk products initially have the same $\mathrm{pH}$ value, as it can be seen in figure 4 . In the same figure, the $\mathrm{pH}$ level has a slowly decrease because of the temperature. The $\mathrm{pH}$ level for UHT decrease faster than the pasteurized even if the value is very small.

Figure 4 illustrates a slowly decrease of $p H$ level from 6.6 to 6.5 for the first 500 minutes.

Next, the test $\mathrm{T}_{2}$ presets $\mathrm{pH}$ evolution for a temperature variation between 12.7 to $23.1^{\circ} \mathrm{C}$ the first 300 minutes. Figure 5 presents that the temperature increases from 12.7

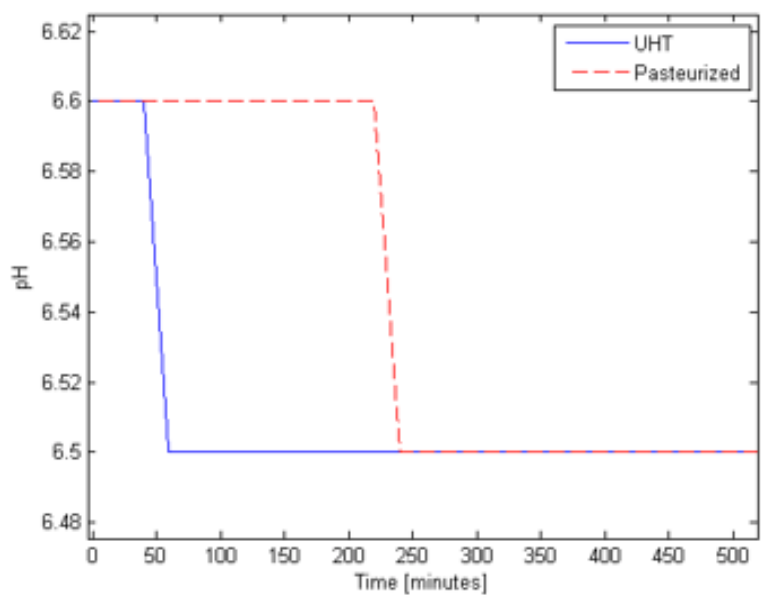

Fig. 4. $\mathrm{pH}$ evolution for both milk probes by modifying the temperature to $23.1^{\circ} \mathrm{C}$ in time, while the $\mathrm{pH}$ level decreases from 6.6 to 6.5. The results for test $T_{2}$ depicted in figure 5 highlights the fact when UHT milk go to 6.5 faster than the pasteurized milk.

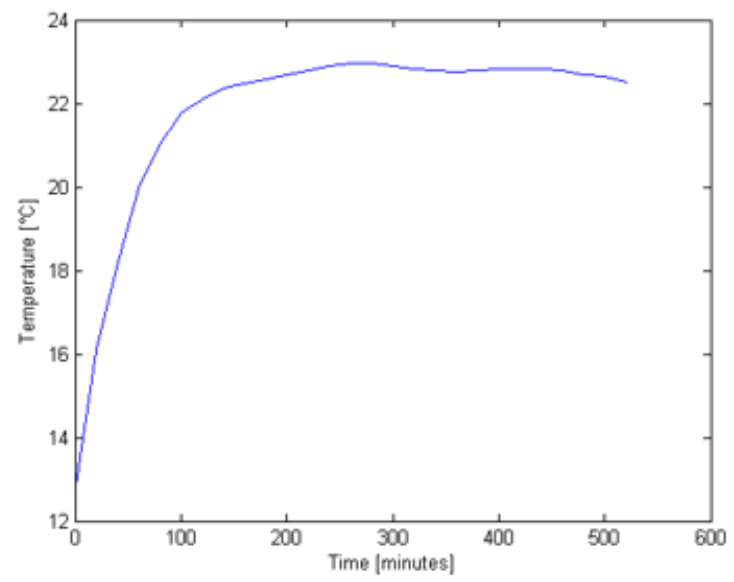

Fig. 5. UHT and pasteurized milk evolution for a temperature increase from 12.7 to $23.1^{\circ} \mathrm{C}$

Test $T$

Results obtained with sour milk for the next 440 minutes of measurement are different, as shown in Figure 6 . The temperature was set to $21-22^{\circ} \mathrm{C}$.

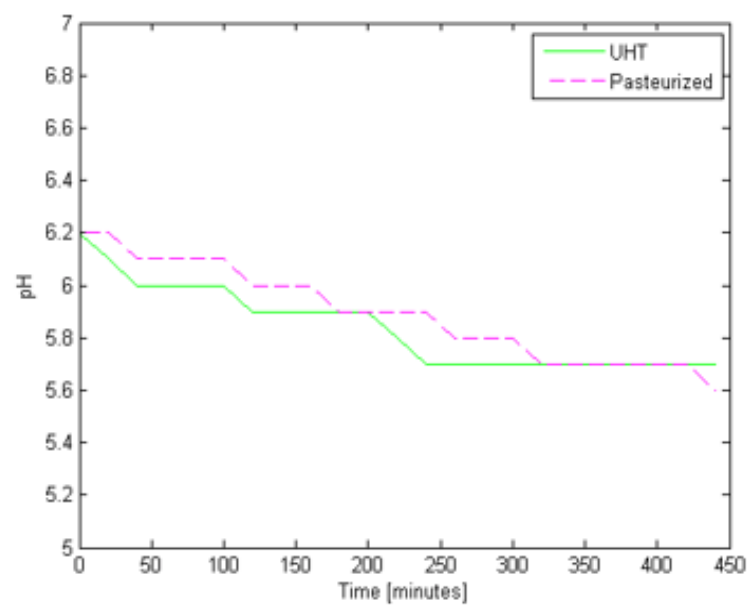

Fig. 6. Test $\mathrm{T}_{3}$ corresponding to $\mathrm{pH}$ measurements continues after 12 hours for both probes

In figure 7 the results show that the $\mathrm{pH}$ decreases from 6.2 to 5.7 for UHT milk and 5.6 for pasteurized milk in 440 minutes with samples acquired every 20 minutes. For the same interval of time, the graphical dependency $\mathrm{pH}$ temperature is presented in figure 7 , when the temperature has a constant increase.

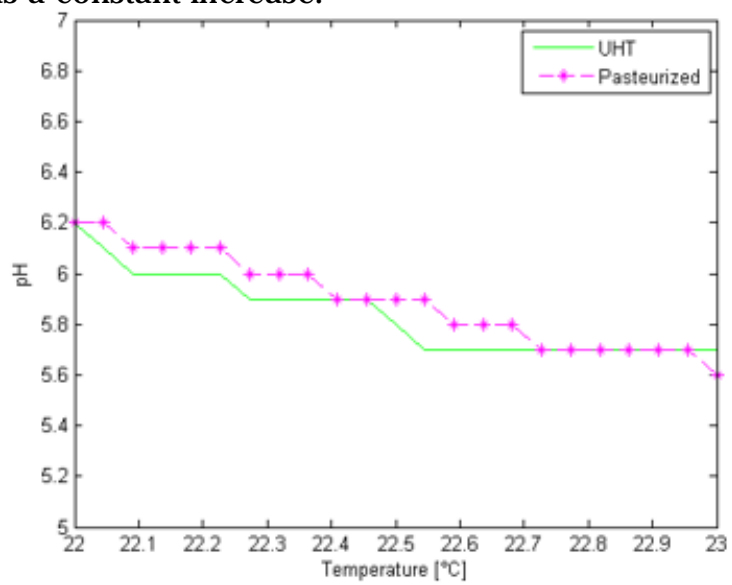

Fig. 7. $p H$ - temperature dependency for test $T_{3}$ http://www.revistadechimie.ro 


\begin{tabular}{|l|l|c|c|c|}
\hline \multirow{2}{*}{ Section } & $\mathrm{T}_{1}$ & $\mathrm{~T}_{2}$ & $\mathrm{~T}_{3}$ \\
\hline \multirow{3}{*}{ S1 } & UHT & 6.6 & $6.6-6.5$ & - \\
\cline { 2 - 5 } & Pasteurized & $6.8-6.5$ & 6.5 & - \\
\hline \multirow{3}{*}{ S2 } & UHT & $6.5-4.0$ & - & $6.5-5.7$ \\
\cline { 2 - 5 } & Pasteurized & $6.5-4.0$ & - & $6.5-5.6$ \\
\hline \multicolumn{2}{|l|}{ Temperature } & $23^{\circ} \mathrm{C}$ & $12.1-23^{\circ} \mathrm{C}$ & $23^{\circ} \mathrm{C}$ \\
\hline
\end{tabular}

Table 1

COMPARATIVE ANALYSISBETWEEN TESTS

$\mathrm{T}_{1}, \mathrm{~T}_{2}$ AND T $\mathrm{T}_{3}$ FOR $\mathrm{pH}$ EVOLUTION
The comparative analysis between $T_{1}, T_{2}$ and $T_{3}$ was possible due to Arduino board inserted in the experimental setup with the purpose to convert the electrical signal acquired from $\mathrm{pH}$ meters probes. In this way, the signal is transmitted to the PC, where the Matlab ${ }^{\circledR}$ application runs continuously. The dedicated developed application counts the time intervals for the next measurement and the acquired data is stored in a database for future processing. The huge advantage of the dedicated application developed for the comparative analysis is represented by the possibility of overlapping graphics due to the Matlab ${ }^{\circledR}$ layout facilities.

Table 1 presents the comparative analysis result for the three tests. The analyzed interval of time was divided into 2 sections: first 16 hours (S1), and next analyzed hours (S2). The second $\mathrm{pH}$ milk factor of influence was temperature. For the comparative analysis, the temperature was maintained to a constant value for some sections, and modified for others, as it can be seen in table 1.

By analyzing the results presented in table 1 , the $\mathrm{pH}$ level for both UHT and pasteurized milk is influenced by time and temperature. The results divide the $\mathrm{pH}$ level by 6.5 limit. In this way, test $T_{1}$ shows that keeping the temperature to $23^{\circ} \mathrm{C}$, the milk acidity will be increased after 12 hours from unpacking. The first test highlights the fact that for the first 16 hours, both UHT and pasteurized milk keep the $\mathrm{pH}$ level indicated for the sweet milk. Also, for this first test, by using a Matlab ${ }^{\circledR}$ application a mathematical model for the $\mathrm{pH}$ variation is obtained from the experimental data and validated using the mean squared error (which is less than 1\%). The second test shows the temperature variation. In this case, the $6.5 \mathrm{pH}$ level is maintained even if the temperature was changed. The second conclusion is that the $\mathrm{pH}$ level for UHT and pasteurized milk is not affected by the storage temperature. The third test illustrates the perishability of milk after 16 hours, when the $\mathrm{pH}$ level decreases below 6.5. The third conclusion that results from this test is that both UHT and pasteurized milk has the same interval of time for souring. The last two tests confirm the proposed $\mathrm{pH}$ value limit and the proposed interval of time achieved at 16 hours.

\section{Conclusions}

A novel study case for $p H$ level and time related to sweet and sour milk was presented. Multiple tests were performed for UHT and pasteurized milk, and the results show that for those two types of milk, the temperature do not affect the $\mathrm{pH}$ level. The study highlights that the first 16 hours from unpacking correspond to $\mathrm{a} p \mathrm{H} \geq 6.5$. In the nexthours, the $\mathrm{pH}$ will decrease as the acidity will increase no matter if the temperature keeps a constant value or is modified. As a general conclusion, the UHT and pasteurized milk can be stored at any temperature for the first 16 hours and the behavior of both products is similar beside the fact that the producers guarantee an extended period of time for UHT milk until the souring process is occurred.

\section{References}

1.LAW N, R., Measurement of pH, in Practical Laboratory Skills Training Guide (ed. Prichard E.), Royal Society of Chemistry, 2003.

2.STETIU, A.A., DANCILA, A., MITARIU, M., SERB, B., MITARIU, M.C., ORMENISAN, A., BARBU, H.M., COMANEANU, R.M., STETIU, M., Rev. Chim.(Bucharest), 67, no. 10, 2016, p. 1966.

3.SCHMID-WENDTNER, M-H., KORTING, H.C., pH and Skin Care, ABW Wissenschaftsverlag $\mathrm{GmbH}, 2007$.

4.ELSNER, P., MERK, HANS F., MAIBACH, HOWARD I., Cosmetics: Controlled Efficacy Studies and Regulation, Springer, 1999.

5.MIHALACHE, S.F., POPESCU, M., RADULESCU, G., Rev. Chim. (Bucharest), 66, no. 9, 2015, p 1459.

6.RUSSELL, N. J ., GOULD, G.W., Food Preservatives, Springer, 2003. 7.DEETH, H., Improving UHT processing and UHT milk products, In Woodhead Publishing Series in Food Science, Technology and Nutrition, Improving the Safety and Quality of Milk, Woodhead Publishing, 2010, p.302.

8.LEEDOM, J.M., Comparing the Food Safety Record of Pasteurized and Raw Milk Products, in Food Poisoning Journal, December11, 2009.

9.MASALOV, V.N., MIKHEYEVA, E.A., ARBUZOV, I.N., J ournal of Agrarian Science, 44, No. 5, 2013, p. 26.

10.KRASAEKOOPT, W., BHANDARI, B., DEETH, H., Australian J ournal of Dairy Technology, 58, No. 1, 2003, p. 26.

11.HELMENSTINE, A.M., What Is the Acidity or pH of Milk?, ThoughtCo,J an. 13, 2019, thoughtco.com/what-is-the-ph-of-milk-603652. 12.RAKIB, R.H., Turbidity index for the detection of heated milk - MS Thesis, Department of Dairy Science, Bangladesh Agricultural University, Mymensingh, 2013.

13.KANWAL, R., AHMED, T., MIRZA, B., Asian J ournal of Plant Sciences,

3, No. 3, 2004, p. 300.

14.ENB, A.,ABOU DONIA, M.A.,ABD-RABOU, N.S.,ABOU-ARAB,A.A.K., EL-SENAITY, M.H., Global Veterinaria, 3, No. 3, 2009, p. 268.

15.HAQ, I., KHASKHELI, M, KIANI, F.A., TALPUR, A.R, LOCHI, G.M., SOOMRO, A.A., SALMAN, M., MARRI, M.Y., MARI, M.M., Journal of Agriculture and Food Technology, 3, No. 8, 2013, p. 5.

16.EL-SALAM, M.H.A, EL-SHIBINY, S., Dairy Sci. \& Technol., 91, 2011, p. 663.

17.VOICU, V., BOMBOS, D., BOLOCAN, I., JANG, C., CIUPARU, D., ReV. Chim.(Bucharest), 63, no. 2, 2012, p. 200.

18.KLEIN, D.R., Organic Chemistry, $2^{\text {nd }}$ Edition, Wiley, 2013.

19.BURTON, H., Ultra High Temperature Processing of Milk and Milk Products, Chapman \& Hall, 1994

20.WALSTRA, P., JENNESS, R., Dairy Chemistry and Physics, John Wiley \& Sons: Canada, 1984.

21.BAUER, R.BIRK, J., SAWYER, D., Laboratory Inquiry in Chemistry, Cengage Learning, 2009.

$\overline{\text { Manuscript received:25.02.2019 }}$ 